\title{
Occult Infection pada Anak Setelah 10 Tahun Mendapat Imunisasi Hepatitis B
}

Asrawati, ${ }^{*}$ Yusri Dianne Jurnalis, ${ }^{*}$ Yanwirasti**

*Departemen Ilmu Kesehatan Anak, **Pasca sarjana Ilmu Biomedik Fakultas Kedokteran Universitas Andalas/RSUP Dr. M.Djamil, Padang

Latar belakang. Occult hepatitis B infection (OBI) adalah suatu keadaan ditemukannya deoxyribose-nucleic acid (DNA) virus Hepatitis B (VHB) pada pemeriksaan HBsAg negatif. Mutasi pada preS2/S menyebabkan sekresi HBsAg menurun sehingga kadar HBsAg dalam serum terlalu rendah yang menyebabkan HBsAg tidak terdeteksi. Virus hepatitis B cenderung mengalami mutasi sebab tidak memiliki sistem koreksi selama replikasi karena tidak adanya 3',5' exonuclease untuk mengkoreksi kesalahan insersi nukleotida saat transkripsi balik.

Tujuan. Mengetahui insiden occult infection setelah 10 tahun mendapat imunisasi hepatitis B.

Metode. Penelitian observasional dengan menggunakan desain cross sectional study pada anak sekolah dasar di Kota Padang dengan jumlah subjek penelitian 40 anak.

Hasil. Jenis kelamin perempuan lebih banyak daripada laki-laki dan status gizi baik lebih banyak dari status gizi kurang. Insiden occult infection ditemukan 10\% pada anak setelah 10 tahun mendapat imunisasi hepatitis $\mathrm{B}$. Tidak terdapat hubungan antara antiHBs dengan occult infection.

Kesimpulan. Occult infection pada anak setelah 10 tahun mendapat imunisasi hepatitis B adalah $10 \%$.

Sari Pediatri 2016;17(5):343-8.

Kata kunci: occult infection, hepatitis B, anak

\section{Occult Infection in Children after 10 Years Immunized Against Hepatitis B}

\author{
Asrawati, ${ }^{*}$ Yusri Dianne Jurnalis, ${ }^{*}$ Yanwirasti**
}

Background. Occult hepatitis B infection (OBI) is a state-discovery of deoxyribose nucleic acid (DNA) in the examination of $\mathrm{HBsAg}$ negative HBV. OBI oftens interpreted as a low viral replication or discovery of mutations in gene $S$ epitope on amino acids 124-147. Mutations in the gene S can occur at preS1 / preS2 / S. Mutations in the preS2 / S causes decreased secretion of $\mathrm{HBsAg}$, results in level of $\mathrm{HBsAg}$ in serum is too low to be detected on conventional examination. Hepatitis B virus is likely to mutate because it does not have a system of correction during replication in the absence of 3', 5' exonuclease to correct nucleotide insertion error during reverse transcription.

Objective. To find out the rate of occult infection in individuals after 10 years been immunized against hepatitis B.

Methods. This study was an observational study using cross sectional design at the elementary school in Padang city with amount of research subjects up to 40 children.

Results. Positive OBI was found more in female children compared to male participants and as well OBI more frequently observed among children with good nutritional status compared to under nourish children. Overall, it was found that incidence of occult Hepatitis B infection was found among $10 \%$ of children after 10 years immunized against hepatitis B. There is no significant relationship between AntiHBs with occult infection.

Conclusion. In this study it was found that there is $10 \%$ Occult Hepatitis B infection, in children after 10 years immunization against hepatitis B. Sari Pediatri 2016;17(5):343-8.

Keywords: occult infection, hepatitis B, children

\footnotetext{
Alamat korespondensi: Dr. Asrawati. Departemen Ilmu Kesehatan Anak FK-UNAND/RS DR.M.Djamil Jl. Perintis kemerdekaan. Padang, Sumatera Barat. Tel. +62(751)811179. Fax.+62(751)811179. E-mail: asrawati1@yahoo.com
} 
I ndonesia merupakan daerah tingkat endemisitas VHB sedang-tinggi, 15 juta orang tercatat telah terinfeksi. Di berbagai daerah di Indonesia, prevalensi hepatitis $B$ surface antigen $(\mathrm{HBs} A g)$ berkisar antara 4\%-20\%, dengan frekuensi terbanyak antara 5\%-10\%. Infeksi VHB pada masa bayi mempunyai risiko kronisitas 70\%-90\%, dan 25\%-30\% di antaranya akan berkembang menjadi sirosis hepatis atau karsinoma hepato selular (KHS). ${ }^{2}$

Occult hepatitis $B$ infection (OBI) adalah suatu keadaan ditemukannya deoxyribose-nucleic acid (DNA) VHB pada pemeriksaan HBsAg negatif. ${ }^{3}$ Virus hepatitis $\mathrm{B}$ cenderung mengalami mutasi karena tidak memiliki sistem koreksi saat replikasi karena tidak adanya 3',5'exonuclease untuk mengkoreksi kesalahan insersi nukleotida saat transkripsi balik. Mutasi pada gen VHB dapat terjadi pada gen $S$, gen precore, gen core, dan gen polymerase. ${ }^{4}$ Dampak OBI adalah hepatitis kronik, atypical alcoholic hepatitis dan KHS, reaktivasi virus, dan transmisi pada tranfusi dan transplantasi organ. ${ }^{5}$ Di Tiongkok, ditemukan occult infection hepatitis B pada genotip C, Hsia dkk $^{6}$ mendapatkan bahwa 31 orang penderita KHS dengan OBI adalah 55\%-56\%, sedangkan Kiiree $\mathrm{dkk}^{7}$ menemukan $17 \%$ di Sinegal. OBI pada anak di Taiwan 10,9\%. ${ }^{8}$ Penelitian Utsumi $\mathrm{dkk}^{9}$ pada murid 18 sekolah dasar ( SD ) di Jawa Timur OBI ditemukan pada 2,3\% anak.

Pemberian imunisasi hepatitis B 3 dosis terbukti berhasil menurunkan prevalensi hepatitis B kronik dan KHS dan memiliki efektivitas $95 \%$ untuk mencegah meningkatnya prevalensi pengidap. ${ }^{10}$ Imunisasi saat ini dikembangkan sesuai dengan variasi genetik virus hepatitis B. Vaksinasi hepatitis B merangsang pembentukan hepatitis $B$ surface antibody (antiHBs) yang seiring dengan waktu mengalami penurunan. Vaksinasi hepatitis B dikatakan gagal jika terdapat $\mathrm{HBsAg}$ positif atau antiHBs kurang dari $10 \mathrm{mIU} /$ $\mathrm{mL}$, dan ditemukan DNA-VHB dengan kadar cut-off serum VHB $<200 \mathrm{IU} / \mathrm{mL} .{ }^{11,12}$ Pemeriksaan DNAVHB dengan nested polymerase chain reaction ( PCR) merupakan pemeriksaan gold standar OBI. ${ }^{13,14}$

Berdasarkan hal tersebut maka dilakukan penelitian untuk mengetahui insiden occult infection pada anak setelah 10 tahun mendapat imunisasi hepatitis B.

\section{Metode}

Penelitian observasional dengan menggunakan desain cross sectional study, dilaksanakan pada lima sekolah dasar (SD) di kota Padang. Pemeriksaan kadar HBsAg dan antiHBsAg dengan pemeriksaan ELISA dan pemeriksaan DNA VHB dengan pemeriksaan PCR dilakukan di Laboratorium Biomedik Fakultas Kedokteran Universitas Andalas. Pemeriksaan sekuensing DNA sampel dikirim ke Laboratorium Macrogen Korea Selatan.

Populasi penelitian adalah murid SD yang berumur 10 tahun yang telah diimunisasi hepatitis B 3 kali. Jumlah subjek penelitian adalah 40 orang. Kriteria inklusi adalah orang tua dan anak setuju ikut dalam penelitian dan mendapat imunisasi hepatitis B 3 dosis. Kriteria eksklusi adalah menderita penyakit keganasan, hepatitis, kelainan hematologi yang memerlukan transfusi darah serial. Semua sampel dilakukan pemeriksaan ELISA HBsAg dan antiHBs dan nested PCR dengan menggunakan 4 pasang primer (Tabel 1.) ${ }^{15}$ Penelitian telah mendapatkan lolos kaji etik dari Komisi Etik Penelitian FK UNAND dengan no. 309/ $\mathrm{KEP} / \mathrm{FK} / 2014$.

\section{Hasil}

Di antara 432 SD yang ada di Kota Padang diambil 5 SD dengan masing-masing 8 orang anak sehingga jumlah total 40 orang anak. Anak perempuan lebih banyak dari laki-laki dan status gizi baik lebih banyak dari status gizi kurang. Insiden occult infection setelah 10 tahun mendapat imunisasi Hepatitis B tertera pada Tabel 3 dan 4.

Dari 40 orang subjek ditemukan HBsAg negatif (100\%), 38 (95\%) orang memepunyai antiHBs. Dari 38 orang dengan antiHBs seroprotektif ditemukan DNA-VHB 4 orang sehingga ditemukan occult infection $10 \%$.

Hasil statistik (Tabel 4) menunjukkan tidak terdapat hubungan antara kadar antiHBs dengan occult infection. Kadar antiHBs pada occult infection lebih rendah (rerata 61,10 IU/L) dari non occult infection (rerata 99,98 IU/L), perbedaan kadar antiHBs tersebut tidak bermakna secara statistik $(\mathrm{p}=0,59)$.

\section{Isolasi dan amplifikasi DNA}

Pada tahap awal dilakukan amplifikasi menggunakan P7 dan P8 dengan band target 520 bp. Hasil PCR negatif dilanjutkan dengan Primer HBS1\&HBS2 
Asrawati dkk: Occult infection setelah 10 tahun mendapat imunisasi hepatitis B

Tabel 1. Primer, lokasi, sekuens dan aplikasi gen S dan gen C VHB ${ }^{15}$

\begin{tabular}{lcrl}
\hline Primer & Lokasi & Sekuens & Aplikasi \\
\hline P7 & $256-278$ & 5'-GTGGTGGACTTCTCTCAATTTTC-3' & Gen S \\
P8 & $796-776$ & 5'-CGGTAWAAAGGGACTCAMGAT-3' & Gen S \\
HBS1 & $455-474$ & 5'-CAAGGTATGTTGCCCGTTTG-3' & Gen S \\
HBS2 & $713-694$ & 5'-AAAGCCCTGCGAACCACTGA-3' & Gen S \\
HBC1 & $1650-1669$ & 5'-TTACATAAGAGGACTCTTGG-3' & Gen C \\
HBC2 & $1744-1761$ & 5'-TAAAGCCCAGTAAAGTTTCC-3' & Gen C \\
HBC3 & $1744-1761$ & 5'-GGGAGGAGATTAGGTTAA-3' & Gen C \\
HBC4 & $2476-2457$ & 5'-CCCACCTTATGAGTCCAAGG-3' & Gen C \\
\hline
\end{tabular}

dengan kondisi yang sama. Hasil PCR dengan primer HBS1 dan HBS2 didapatkan 4 sampel (W18,W28,W30,W35 ) sesuai dengan band target 239 bp (Gambar 1).

Pemeriksaan gen $\mathrm{C}$ dilakukan dengan menggunakan Primer HBC1 dan HBC2 dengan band target 825 bp. Hasil PCR negatif maka dilanjutkan dengan primer HBC3 dan HBC4 dengan kondisi yang sama dengan band target 713 bp dengan hasil negatif.

Tabel 2. Karakteristik subjek penelitian $(\mathrm{n}=40)$

\begin{tabular}{lcc}
\hline Karakteristik & $\mathrm{n}$ & $\%$ \\
\hline Jenis kelamin & & \\
$\quad$ Laki-laki & 15 & 37,5 \\
Perempuan & 25 & 63,5 \\
Status nutrisi & & \\
Baik & 28 & 70 \\
$\quad$ Kurang & 12 & 30 \\
\hline
\end{tabular}

\section{Pembahasan}

Telah dilakukan penelitian untuk mengetahui occult infection hepatitis B pada anak setelah 10 tahun imunisasi hepatitis B. Responden terbanyak adalah perempuan $(63,5 \%)$. Subjek penelitian berjenis kelamin perempuan $63,5 \%$ dan laki-laki $37,5 \%$, status gizi saat imunisasi hepatitis $\mathrm{B}$ ke tiga adalah gizi baik $70 \%$ dan kurang 30\%. Hal yang sama didapatkan Utsumi $\mathrm{dkk}^{9}$ yang melaporkan karakteristik subjek penelitian berjenis kelamin perempuan $50,7 \%$ dan laki-laki 49,3\% pada murid 18 SD di Jawa Timur. Sementara itu, Roznovsky dkk, ${ }^{16}$ di Republik Chechnya, melaporkan jenis kelamin laki-laki 50,2\% dan perempuan 49,8\%. Di Tanzania, jenis kelamin laki-laki $51,7 \%$ dan perempuan $48,3 \%$, sedangkan status gizi normal 70,3\%, kurang 23,6\%, dan buruk 6,1\%. ${ }^{17}$ Di Kota Padang, Aswati dkk ${ }^{18}$ melaporkan

Tabel 3. Distribusi data HBsAg dan antiHBs serta DNA-VHB, occult infection pada anak setelah 10 tahun imunisasi hepatitis B

\begin{tabular}{lccccc}
\hline Hasil pemeriksaan & HbsAg & AntiHBs & DNA -VHB & OBI & $\%$ \\
\hline Positif & 0 & 38 & 4 & 4 & 10 \\
Negatif & 40 & 2 & 36 & 0 & 90 \\
Jumlah & 40 & 40 & 40 & 4 & 10 \\
\hline
\end{tabular}

Tabel 4. Hubungan kadar antiHBs dengan occult infection

\begin{tabular}{|c|c|c|c|c|c|c|c|}
\hline \multirow{2}{*}{ AntiHBs } & \multicolumn{6}{|c|}{ DNA-VHB } & \multirow[b]{2}{*}{$\mathrm{p}$} \\
\hline & Negatif & $\%$ & Positif & $\%$ & Jumlah & $\%$ & \\
\hline Seroprotektif & 34 & 85 & 4 & 10 & 38 & 95 & 1,00 \\
\hline Nonseroprotektif & 2 & 5 & 0 & 0 & 2 & 5 & \\
\hline Jumlah & 36 & 90 & 4 & 10 & 40 & 100 & \\
\hline
\end{tabular}

${ }^{*} \mathrm{p}<0,05$ (bermakna) 


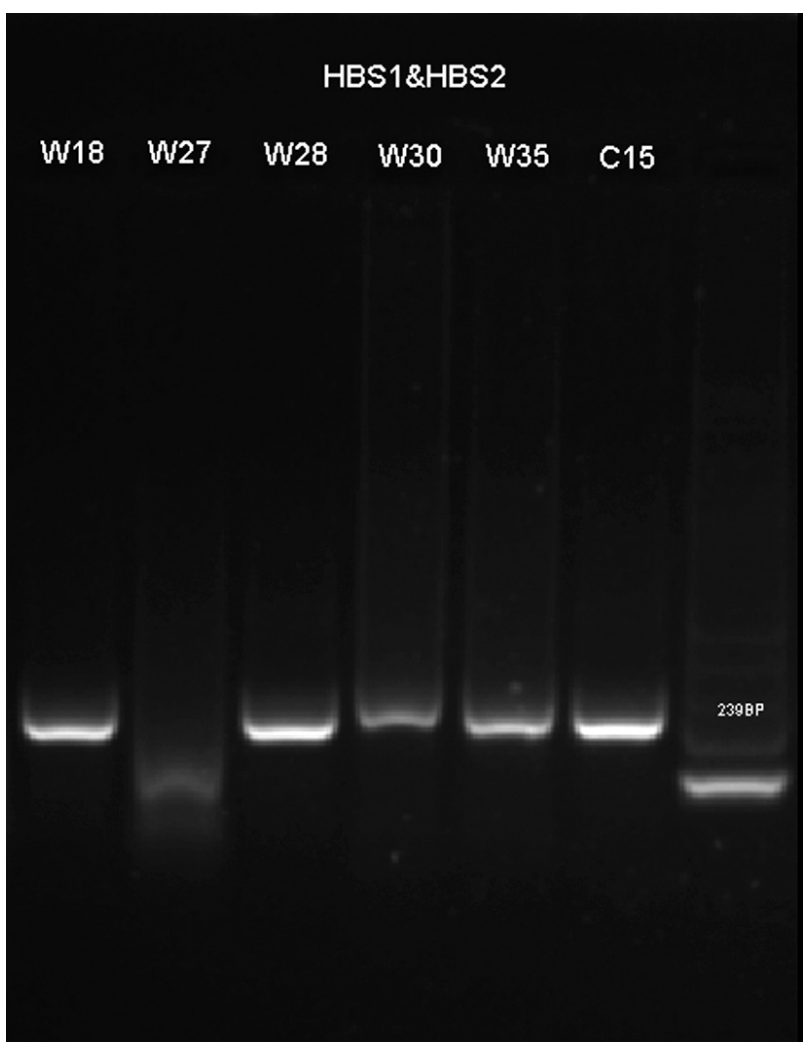

Gambar 1. Elektroforegram hasil PCR HBS1 dan HBS2 dengan band target $239 \mathrm{bp}$.

semua subjek (100\%) penelitian bergizi baik.

Kami mendapatkan 10\% insiden occult infection. Hasil penelitian kami sesuai dengan penelitian $\mathrm{Mu}^{8}$ yang melaporkan $10,9 \%$ insiden occult infection. Utsumi $\mathrm{dkk}^{9}$ melaporkan 2,3\% insiden pada murid 18 SD di Jawa Timur. Chang, ${ }^{19}$ di Taiwan, pada anak setelah imunisasi hepatitis B 15 tahun, melaporkan DNA-VHB positif 7,8\%. Hsia $\mathrm{dkk}^{6}$ melaporkan bahwa 31 orang penderita KHS dengan OBI adalah 55\%$56 \%$, sedangkan Kiiree $\mathrm{dkk}^{7}$ di Senegal melaporkan $17 \%$. Occult hepatitis B infection biasanya disebabkan oleh penekanan yang kuat terhadap replikasi virus dan ekspresi gen. ${ }^{20}$ Mekanisme terjadi occult infection adalah peran sistem imun dan adanya koinfeksi virus hepatitis $\mathrm{C}$ yang menekan keaktifan $\mathrm{VHB}$, terutama dengan antiHbc positif. ${ }^{21}$ Pada skrining tranfusi darah orang dewasa, occult infection didapatkan 10\%-28\%, sedangkan pada anak didapatkan 36\%, 10\%-40\% occult infection menyebabkan terjadinya hepatitis $\mathrm{B}$ kronik. ${ }^{22}$ Pada kasus KHS di Meksiko, OBI ditemukan pada genotip $\mathrm{H} .{ }^{23}$

Salah satu penyebab utama reaktivitas positif palsu adalah keaktifan nonspesifik limfosit B prematur yang menghasilkan molekul terkait IgA atau IgM tanpa didahului dengan paparan terhadap VHB. ${ }^{24}$ Penyebab HBsAg negatif dengan hanya antiHBc positif disebabkan karena HBsAg bersembunyi pada komplek imun, adanya variasi gen pre-S, mutasi pada antigen permukaan sendiri khususnya pada a determinant yang dikenali oleh antiHBs sehingga menyebabkan HBsAg tidak terdeksi oleh cara konvensional. Kemungkinan interferensi sintesis HBsAg oleh infeksi VHC 65,4\% dan penyimpangan hasil pemeriksaan antiHBs $14 \%$. Sebagian orang dengan hanya antiHBc positif mungkin pembawa HBsAg kadar rendah yang tidak terdeteksi, serta disebabkan adanya mutan. Kadar DNA VHB serum biasanya didapatkan kurang dari $10^{4}$ kopi/ mL. ${ }^{25}$

Virus hepatitis B tidak memiliki sistem koreksi saat replikasi sehingga cenderung mengalami mutasi karena tidak ada 3', 5' exonuclease untuk mengoreksi kesalahan insersi nukleotida saat transkripsi balik. Mutasi DNA VHB terjadi dengan kecepatan 1,4-3,2x $10^{5}$ mutasi/ nukleotida/tahun, dengan produksi $10^{10}$ virion/hari dengan waktu paruh 1-2 hari. ${ }^{26}$ Tidak semua mutan bertahan hidup karena susunan ORF saling tumpang tindih. Mutan yang berhasil hidup akan masuk ke dalam serum dan akan mengalami seleksi oleh sistem imun pejamu dan faktor luar, seperti pemberian obat antivirus dan antibodi monoklonal. Dengan demikian, hepatitis B mutan dapat terjadi akibat dari adanya penekanan terhadap virus hepatitis B alamiah karena adanya respon imuologi terhadap virus, penggunaan vaksin, dan terapi antivirus sehingga VHB mutan menjadi dominan dalam populasi. ${ }^{27}$

Beberapa hipotesis mekanisme terjadi OBI adalah vaccine escape mutant DNA-VHB, integrasi DNAVHB pada kromosom host, infeksi mononuclear cells darah perifer, formasi imun komplek VHB, respon imun host dan interferen VHB dengan virus yang lain. ${ }^{25}$

Kami tidak mendapatkan hubungan kadar anti$\mathrm{HBs}$ dengan occult infection dan perbedaan kadar antiHBs. Pada penelitian lain didapatkan OBI dapat terjadi pada seroprotektif dan nonseroprotektif. ${ }^{28} \mathrm{Keja}$ dian OBI pada $20 \%$ nonseroprotektif. ${ }^{29}$ Utsumi dkk $^{19}$ melaporkan bahwa OBI yang seropositif adalah 2 dari 5 subjek (40\%), ${ }^{9}$ sedangkan Chang menemukan VHB DNA pada seroprotektif 98\%-100\%.

Vaksinasi hepatitis B merangsang pembentukan hepatitis $B$ surface antibody (antiHBs) yang seiring 
dengan waktu mengalami penurunan. ${ }^{30}$ Proteksi yang diperlihatkan pada anak yang diimunisasi ketika bayi semakin menurun dengan bertambahnya umur. Di Republik Chechnya dilaporkan daya proteksi pada usia 5, 10, dan 15 tahun adalah $70 \%, 40 \%$, dan $25 \% .{ }^{16} \mathrm{Di}$ Gambian dilaporkan antiHBs tidak ditemukan pada $36 \%$ anak setelah 14 tahun vaksinasi. ${ }^{31}$ Di Padang, Aswati $\mathrm{dkk}^{18}$ melaporkan kadar antiHBs yang protektif ( $\geq 10 \mathrm{mIU} / \mathrm{mL}$ ) pada $47,3 \%$ anak SD setelah $10-12$ tahun vaksinasi. Dosis booster seharusnya diberikan pada umur prasekolah atau remaja. Beberapa penelitian menyarankan untuk pemberian booster setelah 5-15 tahun. ${ }^{32-34}$

Dari penelitian kami dapat disimpulkan bahwa insiden occult infection ditemukan $10 \%$ pada anak setelah 10 tahun mendapat imunisasi hepatitis B lengkap. Terdapat hubungan antara antiHbs dengan occult infection. Penelitian yang dilakukan di beberapa sekolah SD di kota Padang memiliki keterbatasan, yaitu jumlah subjek yang terbatas karena keterbatasan biaya. Untuk itu, penelitian kami belum dapat diterapkan secara umum dipopulasi dan diperlukan penelitian lanjutan untuk mendapatkan kegunaan klinis praktis. Disarankan untuk dilakukan penelitian dengan jumlah subjek penelitian yang lebih besar. Pemberian vaksin hepatitis B sesuai dengan genotip dan subgenotip setiap individu.

\section{Daftar pustaka}

1. Sulaiman A. Hepatitis in Indonesia. In: Nishioka K, Suzuki H, Mishiro S, editors. Viral Hepatitis and Liver Diseases. Proceedings of International Symposium on Viral Hepatitis and Liver Disease:Molecules today. Tokyo: Springer Verlag;1994.h.394-6.

2. Chemin I, Zoulim F. Hepatitis B virus induced hepatocellular carcinoma. Cancer letters, Elsevier 2009;286:52-9.

3. Raimondo G. Statements from the Toarmina expert meeting on occult hepatitis B virus infection. J Hepatol 2008;49:652-7.

4. Osiowy C. Detection of HBsAg mutants. J Med Virol 2006; 1:48-51.

5. Chemin I, Trepo C. Clinical impact of occult HBV infections. J Clin Virol 2005;1:15-21.

6. Hsia CC, Saudamore CH, Di Bisceglie AM, Tabor E. Moleculer and serological aspects of HBsAg negative hepatitis B virus infection in North America. J Med virol
2003;70:20-6.

7. Kiiree CF. The epidemiology and prophylaxis of hepatitis $B$ in sub-Saharan Africa: a view from tropical and subtropical Africa Gut 1996;38:5-12.

8. Mu SC, Lin YM, Jow GM, Chen BF. Occult hepatitis $B$ virus infection in hepatitis $B$ vaccinated children in Taiwan. J Hepatol 2008;50:264-272.

9. Utsumi T, Yano Y. Serologic and molecular characteristics of hepatitis B virus among school children in East Java Indonesia. Am. J. Trop Med 2010;83:189-93.

10. Lu SN, Su WW, Yang SS. Seculer trends and geographic variations of hepatitis B virus and hepatitis $C$ virusassociated hepatocellular carcinoma in Taiwan. Int J Cancer 2006;119:1946-52.

11. Chan HL, Thamson A, Martinof PM, Piratvisuth T, Cornberg M, Rossana M dkk. Hepatitis B surface antigen quantification: Why and how to use it in 2011-A core group report. J Hepatol 2011;8:311-21.

12. Harvat RT. Diagnostic and clinical revelance of $\mathrm{HBV}$ mutations. Lab Me 2011;42:488-96.

13. Danta M. Hepatitis B virus testing and interpreting test result. In B positive-all you wanted to know about hepatitis B: a guide for primary care providers. WJG 2006:31-9.

14. Krajden M, McNabb, Petric. The laboratory diagnosis of hepatitis B virus. Can J Infect Dis Med Microbiol 2005;16:65-72.

15. Lusida MI, Nugrahaputra VE, Soetjipto, Handajani R, Fujii MN, Sasayama M, dkk. Novel subgenotypes of hepatitis B virus genotypes $\mathrm{C}$ and D in Papua Indonesia. J Clin Microbiol 2008;3:2160-6.

16. Roznovsky L, Orsagova I, Klaudova A, Tvrdik J, Kabieszova L, Lochman I, dkk. Long term protection against hepatitis B after newborn vaccination:20-year fooow-up. Infection 2010;38:395-400.

17. Metodi J, Aboud S, Mpembeni R, Munubhi E. Immunity to hepatitis B vaccine in Tanzanian under 5 children. Annals Trop Pediatircs 2010;30:129-36.

18. Aswati L, Jurnalis YD, Sayoeti Y, Bachtiar H. Faktorfaktor yang berhubungan dengan kadar antiHbs pada anak sekolah dasar setelah 10-12 tahun imunisasi hepatitis B di Kota Padang. Sari Pediatri 2013;14:303308.

19. Chang MH. Hepatitis B virus mutation in children. Indian J of Pediatrics 2006;73:803-807.

20. Raimondo G, Caccamo G, Filomia R, Pollicino. Occult HBV infection. Semin Immunopathol 2013;35:39-52.

21. Mulrooney CPM, Michalak TI. Persistent occult hepatitis $B$ virus infection experimental finding and critical 
implications. World J Gastroenterol 2013;13:5682-6.

22. Liu CJ, Lo SC, Kao JH, Tseng PT, Lai MY, Ni YH. Transmission of occult hepatitis $\mathrm{B}$ virus by transfusion to adult and pediatric recipients in Taiwan. J of Hepatology;Elsevier 2006;44:39-46.

23. Minuk GY, Sun DF, Uhanova J, Zhang M, Caouette $S$, Nicolle LE, dkk. Occult hepatitis B virus infection in North American community based population. J Hepatol 2005;42:480-5.

24. Lachenbruch PA, Yu MY. Quantification of hepatitis B virus genomes and infectivity in human serum samples. Transfusion 2006;46:1829-35.

25. Samal J, Kandpal M, Vivekanandan P. Moleculer Mechanisms Underlying Occult Hepatitis B Virus Infection. Clin Microbiol Rev 2012;25:142-63.

26. Romero M, Madejon A, Rodriguez CF, Samaniego JG. Clinical significance of occult hepatitis B virus infection. World J Gastroenterol 2011;17:1549-52.

27. Fallahian F, Zamani F. Hepatitis B vaccine: Immunity, efficacy and types. Shiraz E Med J 2010;11:39-54.

28. De Maddalena C, Soriano V. High level of genetic heterogeneity in $\mathrm{S}$ dan $\mathrm{P}$ genes og genotype $\mathrm{D}$ hepatitis virus. Virology 2007;365:113-24.
29. Pennie RA, Kang CY. High prevalence of occult hepatitis $\mathrm{B}$ among immigrant students in Canada: A case for universal immunization of young adult. Can J Infect Dis 1993;4:105-7.

30. Avellon A, Echevarria JM. Frequency of hepatitis B virus a determinant variant in unselected Spanish chronic carriers. J Med Virol 2006;78:24-36.

31. Whittle H, Jaffar S, Wansbrough M, Mendy M, Dumpis Ud. Observational study o vaccine efficacy 14 years after trial of hepatitis B vaccination in Gambian children. Br Med J 2002;325:569-74.

32. Damme P, Moiseeva A, Marichev ID. Five years followup following two or three doses of a hepatitis B vaccine in adolescents aged 11-15 years: a randomised controlled study BMC Infect Dis 2010;10:1-8.

33. McMahon B, Bruden D, Petersen K, dkk. Antibody level and protection after hepatitis $B$ vaccination : results of a 15-year follow-up. Ann Intern Med 2005;142:333-41.

34. Hammitt LL, Hennessy TW, Fiore AE, Zanis C, Hummel $\mathrm{KB}$, Dunaway E, dkk. Hepatitis B immunity in children vaccinated with recombinant hepatitis $B$ vaccine beginning at birth: a follow-up study at 15 years. Vaccine 2007;25:6958-64. 